\title{
Growth of mastigocladus (Cyanobacteria) HS-46 isolated from maribaya hot spring, indonesia in medium NPK as a potential biofuel feedstock
}

\author{
Alinda Nurmarina ${ }^{1}$, Nurul Rakhmayanti ${ }^{1}$, Nining Betawati Prihantini ${ }^{1, *}$, Sri Handayani ${ }^{2}$, and Nasruddin ${ }^{3}$ \\ ${ }^{1}$ Departement of Biology, Faculty of Mathematics and Natural Sciences, University of Indonesia, 16424 UI Depok, Indonesia \\ ${ }^{2}$ Departement of Chemistry, Faculty of Mathematics and Natural Sciences, University of Indonesia, 16424 UI Depok, Indonesia \\ ${ }^{3}$ Departement of Mechanical Engineering, Faculty of Engineering, University of Indonesia, 16424 UI Depok, Indonesia
}

\begin{abstract}
One of cyanobacteria genera which isolated from Maribaya hot spring located in Indonesia is Mastigocladus HS-46 can be used as raw material for biofuel production. Mastigocladus is cultured in commercial NPK fertilizer. Commercial NPK fertilizer is one of the low cost medium that commonly used for microalgae growth. The research aims to know the best concentration of commercial NPK fertilizer for Mastigocladus HS-46 growth. In this research, Mastigocladus HS-46 was grown in commercial NPK fertilizer with concentration 80 ppm, 240 ppm, NPK 80 ppm+BBM, and BBM (Bold Basal's Medium) as a control. This strain was incubated on $35^{\circ} \mathrm{C}$. Observation were made approximately 14 days with 2 sampling for each medium. The average of wet weight Mastigocladus HS-46 after 14 day observation was obtained at NPK 80 ppm: 0,019 g/L, NPK 240 ppm: 0.009 g/L, NPK+BBM: 0,014 g/L, and BBM: 0,015 g/L. The results showed that the best NPK medium concentration was $80 \mathrm{ppm}$ for growth Mastigocladus HS-46. Commercial NPK fertilizer can be used for growth Mastigocladus HS-46 which has potential as biofuel feedstock.
\end{abstract}

\section{Introduction}

One of the genera of cyanobacteria that can live hot spring, namely Mastigocladus sp. Mastigocladus HS-46 was isolated from the Maribaya hot spring in Indonesia. Mastigocladus HS-46 lives at $42{ }^{\circ} \mathrm{C}$ and $\mathrm{pH} 6$ [1]. Mastigocladus is potentially as a raw material for the production of biofuels, because biomass Mastigocladus contain lipid which can be used as a raw material for the production of biofuels [2]. The benefits of using microalgae including cyanobacteria as a raw material for biofuels, that is in the process of harvesting can be done continuously, the cost of harvesting and transportation relatively low, and also does not require extensive land in breeding [3]. to be able to produce biofuel, it takes high amounts of biomass. Therefore, it needed a growth medium for growing cyanobacteria so it can produce a high amount of biomass that can be used as raw material for the production of biofuels.

Growth medium containing nutrient for the growth of cyanobacteria. The growth medium commonly used for the growth of microalgae including cyanobacteria is Bold Basal's Medium. The Bold Basal's medium has a complete macronutrient and micronutrient [4] to serve as a medium control for the study. Nevertheless, the use of medium BBM to growing cyanobacteria in large scale research that leads to the production of biofuels is not economically. Therefore, to produce a high biomass needed an economical alternative medium.

In addition to the Bold Basal's Medium, NPK fertilizers can be used as microalgae growth mediums [5]. NPK Fertilizer is an inorganic fertilizer with macronutrient composition consisting of $\mathrm{N}, \mathrm{P}$, and $\mathrm{K}$ which is essential and commonly used in plants to support its growth [6]. Other than as a plant fertilizer, NPK fertilizer can also be used to grow the cyanobacteria because it has enough content of nutrients for the growth of cyanobacteria.

This study is a basic study to find alternative medium, that is using NPK fertilizer to grow Mastigocladus HS-46 in order to produce high biomass. Research is expected to continue in large scale research leading to the biotechnology sector to produce biofuels.

\section{Method and Materials}

\subsection{Microorganisms and Growth Medium}

The microorganisms which used in this study was cyanobacteria genus Mastigocladus strain HS-46. Mastigocladus HS-46 was isolated from Maribaya hot spring. Mastigocladus HS-46 were grown in growth medium BBM as a control medium, and medium NPK

* Corresponding author: nining.prihantini@gmail.com 
fertilizer with variations concentrations $80 \mathrm{ppm}, 240$ ppm, and medium NPK fertilizer mix with BBM (NPK $80 \mathrm{ppm}+\mathrm{BBM})$.

\subsection{Method}

The first step of cultivation cyanobacteria is inoculated $30 \mathrm{mg}$ biomass into growth medium. Amount $70 \mathrm{~mL}$ of growth medium were added into Erlenmeyer flask 100 $\mathrm{mL}$. Mastigocladus HS-46 was incubated in an incubator at temperature $35^{\circ} \mathrm{C}$ and light intensity \pm 3300 lux, with initial $\mathrm{pH}$ 6-6.5 with two repetitions.

\subsection{Measurement the weight of wet biomass Mastigocladus HS-46}

Measurement of Mastigocladus HS-46 were done in 14 days with 10 times of observation. The sterile eppendorf tube $1.5 \mathrm{~mL}$ was measured at analytical measurement tool. Eppendorf tube with biomass were sentrifuged for 10 minute with $10.000 \mathrm{rpm}$. The supernatant were taken out and wet biomass weight were measured with analytical measurement tool.

\subsection{Preparation and processing of data}

This research is descriptive. Observation data include quantitative and qualitative data. Quantitative data in the form of weight biomass $(\mathrm{g} / \mathrm{L})$ and the qualitative data in the form of a color culture of Mastigocladus HS-46. Data weight biomass will be shown in the form of tables and curves while the color culture of Mastigocladus HS46 will be shown in the photos of microscopic. Growth curve was made by comparing the value of biomass weight as ordinate axis $\mathrm{Y}$ by biomass weight counting time as abscissa $X$. The growth curves were made by Microsoft Excel.

\section{Results and Discussion}

\subsection{Macroscopic observation Mastigocladus HS- 46}

Macroscopic observations of Mastigocladus HS-46 cultures by comparing the culture color on the Faber Castle standard color [7]. Based on the color chart, the color of the starter culture Mastigocladus HS-46 is sea green (Fig.1). The color appereance of Mastigocladus HS-46 in medium NPK 80 ppm dan 240 ppm was changed from sea green into apple green at day $14\left(\mathrm{t}_{14}\right)$. while Mastigocladus HS-46 in BBM and NPK+BBM not changed and still colored sea green at day 14 (Fig.2)

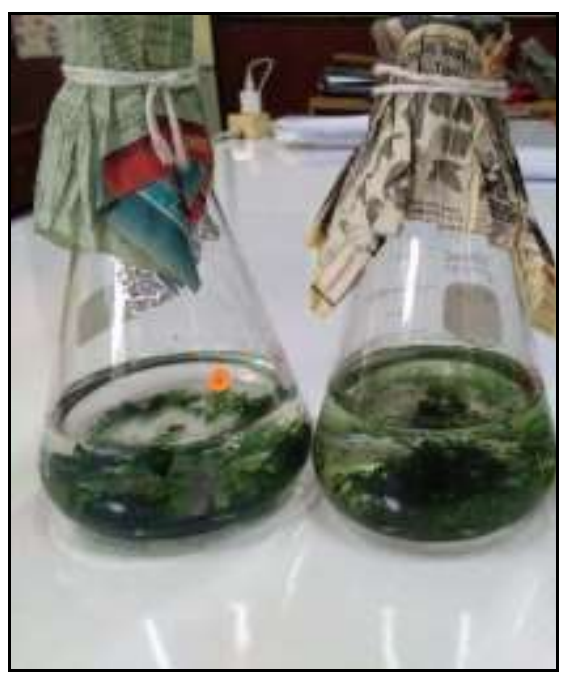

Fig. 1. Macroscopic sightings starter cultures Mastigocladus HS-46 in the Erlenmeyer flask is colored sea green.

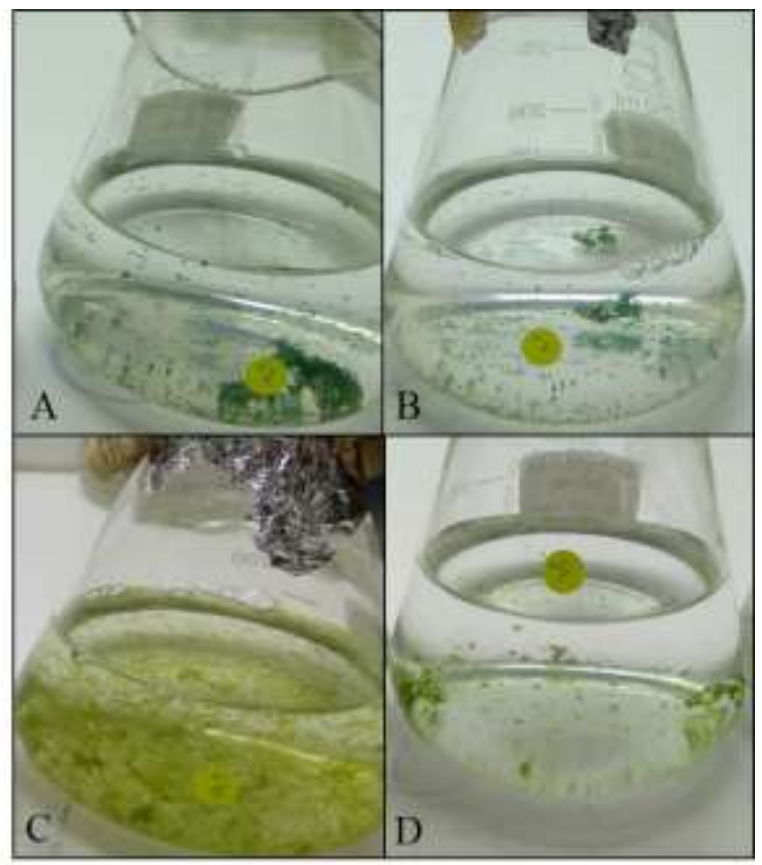

Fig. 2. Cultures color difference of Mastigocladus HS-46 in medium BBM (A), medium NPK+BBM (B), NPK 80 ppm (C), and NPK $240 \mathrm{ppm}$ (D). Mastigocladus HS-46 in BBM medium and $\mathrm{NPK}+\mathrm{BBM}$ medium not changed and still coloured sea green, while Mastigocladus HS-46 is grown in NPK medium $80 \mathrm{ppm}$ and $240 \mathrm{ppm}$, changing colour from green sea to apple green.

The color change that occurs in the Mastigocladus HS46 grown in medium NPK $240 \mathrm{ppm}$ and $80 \mathrm{ppm}$, probably due to the chlorophyll degradations process. The process of chlorophyll degradation mechanism can occur due to the reaction of phaeophytin formation. Phaeophytin is a form of chlorophyll that loses the $\mathrm{Mg}^{2+}$ ion. The process begins with the presence of $\mathrm{Mg}^{2+}$ ions in the middle of the molecule. Furthermore, the $\mathrm{Mg}^{2+}$ ion will be removed, and replaced by hydrogen ions. Consequently the color expressed becomes yellow [8]. 
Therefore Mastigocladus HS-46 grown in medium NPK $80 \mathrm{ppm}$ and NPK $240 \mathrm{ppm}$ change color to apple green.

\subsection{Biomass Weight Mastigocladus HS-46}

Mastigocladus HS-46 culture growth was seen in changes in the amount of biomass weight. Measurement of biomass weight of culture was done on day $0(\mathrm{t} 0)$, day $1\left(\mathrm{t}_{1}\right)$, day $2\left(\mathrm{t}_{2}\right)$, day $3\left(\mathrm{t}_{3}\right)$, day $4\left(\mathrm{t}_{4}\right)$, day $7\left(\mathrm{t}_{7}\right)$, day 8 $\left(\mathrm{t}_{8}\right)$, day $11\left(\mathrm{t}_{11}\right)$, day $12\left(\mathrm{t}_{12}\right)$, and day $14\left(\mathrm{t}_{14}\right)$.

Table 1. The average weight ratio of Mastigocladus HS-46 biomass in medium BBM, NPK 80 ppm, NPK 240 ppm, and $\mathrm{NPK}+\mathrm{BBM}$ at observation time for 14 days

\begin{tabular}{|c|c|c|c|c|}
\hline \multirow{2}{*}{$\begin{array}{c}\text { Time } \\
\text { (Day) }\end{array}$} & \multicolumn{4}{|c|}{ Biomass weight (g/L) } \\
\cline { 2 - 5 } & BBM & $\begin{array}{c}\text { NPK } \\
80 \\
\text { ppm }\end{array}$ & $\begin{array}{c}\text { NPK } \\
240 \\
\text { ppm }\end{array}$ & $\begin{array}{l}\text { NPK } \\
+ \\
\text { BBM }\end{array}$ \\
\hline $\mathrm{t}_{0}$ & 0.003 & 0.003 & 0.003 & 0.003 \\
\hline $\mathrm{t}_{1}$ & 0.001 & 0.001 & 0.002 & 0.001 \\
\hline $\mathrm{t}_{2}$ & 0.003 & 0.003 & 0.006 & 0.003 \\
\hline $\mathrm{t}_{3}$ & 0.013 & 0.003 & 0.005 & 0.002 \\
\hline $\mathrm{t}_{4}$ & 0.007 & 0.003 & 0.005 & 0.008 \\
\hline $\mathrm{t}_{7}$ & 0.013 & 0.005 & 0.015 & 0.018 \\
\hline $\mathrm{t}_{8}$ & 0.015 & 0.013 & 0.009 & 0.014 \\
\hline $\mathrm{t}_{11}$ & 0.001 & 0.013 & 0.018 & 0.017 \\
\hline $\mathrm{t}_{12}$ & 0.003 & 0.014 & 0.004 & 0.014 \\
\hline $\mathrm{t}_{14}$ & 0.015 & 0.019 & 0.009 & 0.014 \\
\hline
\end{tabular}

Based on Table 1. the results of the mean weight calculation of Mastigocladus HS-46 biomass in all treatments decreased from day $0\left(\mathrm{t}_{0}\right)$ to day $1\left(\mathrm{t}_{1}\right)$. Mastigocladus HS-46 grown in BBM medium increased biomass on day $3\left(\mathrm{t}_{3}\right): 0.013 \mathrm{~g} / \mathrm{L}$; day $8\left(\mathrm{t}_{8}\right): 0.015 \mathrm{~g} / \mathrm{L}$; and day $14\left(\mathrm{t}_{14}\right): 0.015 \mathrm{~g} / \mathrm{L}$.

Mastigocladus HS-46 grown in NPK $80 \mathrm{ppm}$ increased biomass on day $8\left(\mathrm{t}_{8}\right): 0.013 \mathrm{~g} / \mathrm{L}$; day $12\left(\mathrm{t}_{12}\right)$ : $0.014 \mathrm{~g} / \mathrm{L}$; and day $14\left(\mathrm{t}_{14}\right): 0.019 \mathrm{~g} / \mathrm{L}$. Mastigocladus HS-46 grown in NPK $240 \mathrm{ppm}$ increased biomass on day ke-7 $\left(\mathrm{t}_{7}\right)$ sebesar $0.015 \mathrm{~g} / \mathrm{L}$ and day $11\left(\mathrm{t}_{11}\right): 0.018$ $\mathrm{g} / \mathrm{L}$. Then decreased on day $14\left(\mathrm{t}_{14}\right): 0.009 \mathrm{~g} / \mathrm{L}$. Mastigocladus HS-46 grown in NPK+BBM medium increased biomass on day ke-18 $\left(\mathrm{t}_{18}\right): 0.018 \mathrm{~g} / \mathrm{L}$. Then decreased on day $14\left(\mathrm{t}_{14}\right): 0.014 \mathrm{~g} / \mathrm{L}$.

The result of qualitative observation using growth curve shows Mastigocladus HS-46 difference which is grown in variation medium of BBM, medium NPK 80 ppm, $240 \mathrm{ppm}$, and NPK+BBM. The difference can be seen in Fig.4.

The growth curve of this study still imperfect, because Mastigocladus HS-46 were still adapted with the condition of growth medium [5]. The growth curve can increase and decrease again so it has not reached stable. This is because the medium BBM, NPK $80 \mathrm{ppm}$, and NPK 240 ppm, has a high nitrogen content. Nitrogen contained in the medium is a major nutrient in the growth of microalgae including cyanobacteria. Nitrogen function in biochemical processes, such as the biosynthesis of nucleic acids (DNA and RNA) and amino acids (protein). Cyanobacteria use sources of nitrogen in the form of $\mathrm{NH}_{4}^{+}, \mathrm{NO}_{3}^{-}, \mathrm{NO}_{2}^{-}$, and $\mathrm{NO}^{-}$and also organic molecules in the form of urea and amino acids [9]. The source of nitrogen in the medium BBM from $\mathrm{NaNO}_{3}$ while the nitrogen source in the NPK medium from amonium $\left(\mathrm{NH}_{4}^{+}\right)$; nitrat $\left(\mathrm{NO}_{3}{ }^{-}\right)$; and urea. High levels of nitrogen in the growth medium can lead to the deactivation of pigment production for photosynthesis [5]. Therefore, mediums that have high nitrogen levels take longer to reach a stable phase of growth. The nitrogen content in the BBM medium was $41.17 \mathrm{mg}$, while the nitrogen content of NPK medium 80 ppm and $240 \mathrm{ppm}$ was $16 \mathrm{mg}$ and $48 \mathrm{mg}$.

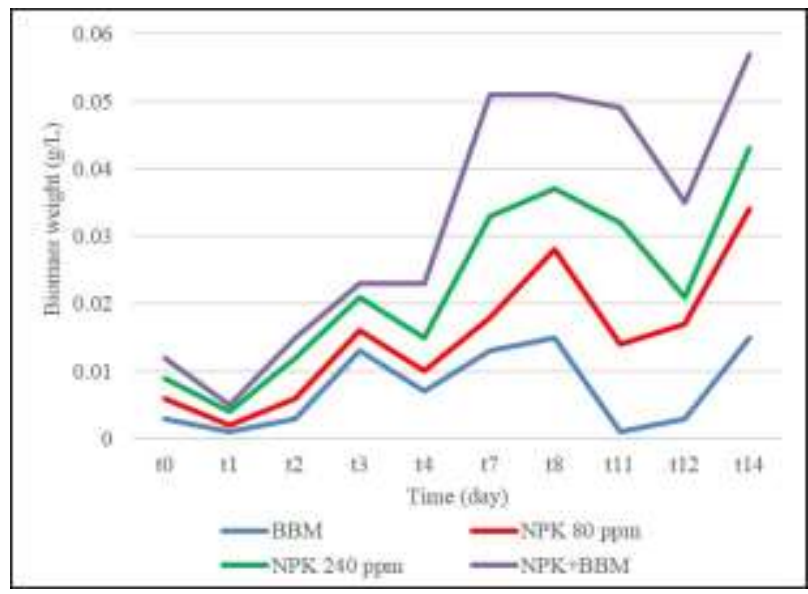

Fig.4. Growth curve of Mastigocladus HS-46 in BBM medium; NPK 80 ppm; NPK 240 ppm; and NPK+BBM.

\section{Conclusion}

Based on the observation of the 14 day and the discuccion that has been done. The medium concentration of NPK $80 \mathrm{ppm}$ is the best concentration of NPK for Mastigocladus HS-46 growth, because the average biomass weight Mastigocladus HS-46 in NPK $80 \mathrm{ppm}$ on day $14\left(\mathrm{t}_{14}\right): 0.019 \mathrm{~g} / \mathrm{L}$. The low average biomass weight in Mastigocladus HS-46 grown in NPK medium $240 \mathrm{ppm}$ on day $14\left(\mathrm{t}_{14}\right): 0.009 \mathrm{~g} / \mathrm{L}$.

This work was funded by Hibah Publikasi Internasional Terindeks untuk Tugas Akhir Mahasiswa (Hibah PITTA) 2018 to Nining Betawati Prihantini, grant no. 2288/UN2.R3.1/HKP.05.00/2018.

\section{References}

1. Prihantini, N.B. Polyphasic taxonomy of culturable Cyanobacteria isolated from hot spring in west java, Indonesia. Disertasi S3 Jurusan Biologi FMIPA UI, Depok: vii + 213 hlm (2015)

2. Kotelev, M.S. Antonov, M. S. Beskorovainyi A. V. \& Vinokurov, V. A. Photobioreactor operation condition optimization for high energy cyanobacterial biomass synthesis to prodce third 
generation biofuels. Chemistry and Technology of Fuels and and oils (2013)

3. Mudasir, M. \& Suyono, E. Potensi algae sebagai biofuel. Universitas Gadjah Mada, Departemen Kimia, FMIPA, Yogyakarta: $17 \mathrm{hlm}$ (2010)

4. Andersen, R. A., J.A. Berges, P.J. Harrison \& M.M.Watanabe. Appendix a recipes for freshwater and seawater media. in: Andersen, R.A (ed.). Algal culturing techniques. Elsevier Academic Press, Elsevier Inc, London: $538 \mathrm{hlm}$ (2005)

5. Saad, A. H, Cultivation of microalgae Chlorella vulgaris in Airlift photobioreactor for biomass production using comemercial NPK nutrients. Alkhwarizmi Engineering 12, 1 (2015)

6. Amini, S \& Syamdidi. Konsentrasi unsur hara pada media dan pertumbuhan Chlorella vulgaris dengan pupuk anorganik teknis dan analisis. Jurnal Perikanan 2 (2006)

7. Faber castell polychromos artist color pencils. 5 hlm.http://www.fabercastell.com/service/colorcharts, diakses 27 Mei 2018, pk 20.15 WIB.

8. Brandis, A. S., Salomon, Y., \& Scherz, A. Advences in Photosynthesis and chlorophyll a to chlorophyll $\mathrm{b}$ ratio of Chlorella. Plant Physiology 46, 1 (2006)

9. Markou, G., D. Vandamme, K. Muylaert. Microalgal and Cyanobacterial cultivation: The supply of nutrients. Water research. 65 (2014) 